\title{
Advanced Nanostructures for Cell Membrane Poration
}

\author{
Apresio K. Fajrial ${ }^{1}$ and Xiaoyun Ding ${ }^{1, *}$ \\ 1 Department of Mechanical Engineering, University of Colorado Boulder, Boulder, CO, USA 80309 \\ *E-mail: xiaoyun.ding@colorado.edu \\ Received xxxxxx \\ Accepted for publication $\mathrm{xxxxxx}$ \\ Published xxxxxx
}

\begin{abstract}
Nanostructured devices have been able to foster the technology for cell membrane poration. With the size smaller than the cell, nanostructure allows efficient poration on the cell membrane. Emerging nanostructures with various physical transduction have been demonstrated to accommodate effective intracellular delivery. Aside from improving poration and intracellular delivery performance, the nanostructured device also allows the discovery of novel physiochemical phenomenon and biological response of the cell. This article provides a brief introduction to the principles of the nanostructured device for cell poration and outlines the intracellular delivery capability of the technology. In the future, we envision more exploration on new nanostructure designs and creative applications in biomedical fields.
\end{abstract}

Keywords: cell membrane disruption, cell poration, intracellular delivery, nanostructure

\section{Introduction}

The capability to access the inner compartment of mammalian cells is important for biomedical applications. One such example, like increasing the permeability of the cell membrane, allows the delivery of chemicals or genetic agent into the cell which is the stepping stone in manipulating cell behavior. Introduction of foreign materials into the cells could induce various cells responses such as modulation of gene expression and differentiation of specific cell [1-5]. Besides cargo delivery, intentionally forming pores in the cell membrane enables the harvesting of the intracellular component. For decades, researchers collect protein and nucleic acid from the cell by breaking the cell membrane [6]. This process, popularly known as cell lysis, is conducted by exposing the cell to chemical agents, either enzymes, detergent, or by applying mechanical disruption. However, deteriorating the whole cell membrane will ultimately kill the cell.
Various technology has been developed to ensure the formation of pores in the cell membrane without compromising the cell viability. Electroporation is one of the most successfully commercialized methods to create temporary pores in the cell membrane and deliver cargo into the cell. This method utilizes the electric field to cause a charge gradient across the cell. The local electric field gradient around the plasma membrane drives the water molecule thus increasing the chance for water penetration which at the same time producing the pore on the membrane [7]. In 1982, Neumann et al demonstrate that electroporation is able to transfer the gene into mouse fibroblast cell and it has been popularly used for transfecting gene to other types of the cell ever since [8]. The molecular transport on the porated membrane can be facilitated by the electrical drift for large molecule or diffusion for small molecule [9]. Unfortunately, the common bulk process of electroporation is not capable to produce uniform electric field influence to all the treated cell. The size and the distribution of the pore on the membrane, 
thus, are not homogeneous and may not allow the specific substance to be delivered [10].

Aside from chemical agent and electrical field, many other physical methods have been demonstrated to break cell membrane efficiently. [11]. Ultrasound acoustic cavitation shock wave has been able to accommodate DNA transfection into mammalian cells [12-14]. Moreover, shear stress from the oscillating bubble produced by the acoustic wave is able to compromise the cell membrane integrity. Beside acoustic energy, mechanical force to break the cell membrane can be introduced by the fluid flow. A high-speed jet flow of solution with cargo can penetrate the cell seamlessly in vivo [15]. Likewise, shear stress from micromechanical structure also allows a high transfection rate [16]. Similar to the acoustic shock wave, the laser can generate highly localized energy which wounds the cell membrane [17,18]. Although the throughput is far less than the ultrasonic device, the precision of the laser allows a specific cell to be targeted with high efficiency [19,20].

The emerge of nanotechnology has shed light on new cell membrane poration technology. With the size of up to a few hundred nanometers, nanotechnology has the perfect scale to manipulate the cell and its organelles whose dimensions are in the order of few microns. By using a submicron structure, the cytosol is accessible for interrogation with minimal disruption to the cell. In drug delivery study, nanotechnology gains a huge fame especially due to its role in enhancing the efficacy and specific targeting of the drug into the target site [21]. Additionally, the power of nanotechnology is capable to alleviate specific limitation of former cell poration technology by providing precision and accuracy, reducing the adverse effect, and increasing yield and efficiency of the method.

In this article, we provide a summary of recent technology for cell membrane poration that utilizes nanostructures. Specifically, we discuss the advanced nanostructures that are implemented as a platform for cell membrane poration. Therefore, nanoparticles that may be consumed by the cell, such as quantum dots, silica nanoparticle, and metal nanoparticle, are not covered in the discussion. We describe several poration mechanisms of the nanostructure and categorize it based on the transduction principle that determines the poration mechanism. We examine the performance for cargo delivery of the various nanostructurebased cell membrane poration technology. Finally, we will also provide insight into the new opportunities of nanotechnology for cell membrane poration and molecular cell biology applications.

\section{Mechanical Poration}

Mechanical poration is the most straightforward mechanism for breaking the cell membrane. In general, the mechanical poration is analogous to surgeon blade cutting the patient tissue. The mechanical forces cause enough stress on (a)

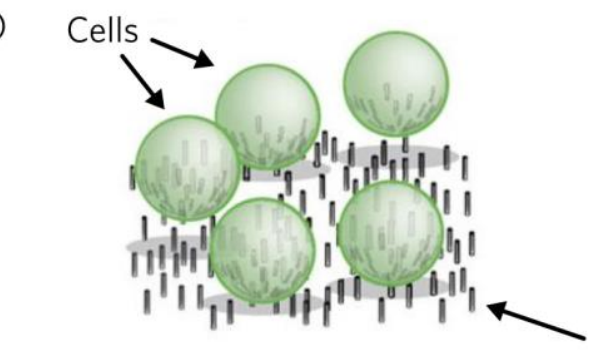

(b)

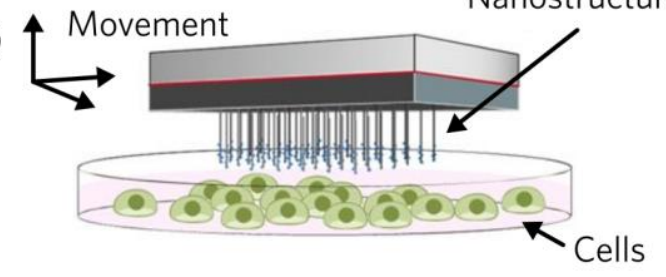

Figure 1. Device operation in nanostructure mechanical poration. (a) Seeding of the cell on the nanostructure, adapted with permission from [22], Copyright 2014 Springer Nature. (b) Spatially controlling the nanostructure, adapted from [23].

the cell which generates discontinuity to the plasma membrane. In a mammalian cell, lipid bilayer composing the plasma membrane is typically around 10 nanometers thick and might vary depending on the chemical content of the layer [24]. Therefore, a mechanical structure with a larger feature than the lipid bilayer thickness is supposedly capable to break the plasma membrane.

Nanostructure has been proven to enhance cell membrane disruption. For example, nanoscale barb developed by $\mathrm{Di}$ Carlo et al efficiently lysed cell and improves the accessibilities of the protein content [25]. The barbs have a really sharp tip with a radius of curvature smaller than $25 \mathrm{~nm}$. Similar with nanoscale barb, arrays of silicon pillar with a sharp tip, called nanoblade, can rapidly lyse the cell with better protein extraction performance compared to chemical cell lysis [26]. Random formation of the sharp tip such as the hierarchical silicon nanospikes and nanowires also allow high throughput protein extraction and at the same time isolating the genetic materials of the target cells [27-29]. Although the main reason for improvement for lysate extraction using sharp nanostructure is not clearly understood, we assume that the nanostructure acts as a fine grater for the cell. In comparison to chemical lysis employing detergent to compromise the cell membrane, mechanical nanostructure combined with the driving force from the fluid flow rupture the plasma membrane through strong shear stress owing to the sharp nanoscale tips. In addition, incorporating detergent or other chemicals for lysis may cause denaturation of the protein and other biomolecules. The absence of any chemical in the mechanical lysis procedure preserves the biochemical content of the cells. This reason might also explain the higher 
extraction yield of the nanostructured devices compared to chemical lysis.

For cell lysis, the mode of operation is usually by flowing the cell through the structure. Oftentimes, this type of mode of operation integrates the nanostructure in a microfluidic channel where the cell is flown. However, for the cell poration, the mode of operation needs to ensure it is minimally invasive to the cell and maintain the cell viability. Figure 1 represents the mode of operation for the cell poration using mechanical nanostructure. Devices harnessing mechanical energy for cell poration are usually operated by seeding the cell right on the nanostructured materials or by controlling the nanostructure itself. High aspect ratio nanostructures, such as vertically-aligned nanowires, are capable of direct penetration to the cell membrane as the cell spread over the substrate [30]. Whereas, a single nanostructure like nanopipette and nanoneedle, fabricated by modifying AFM tip, can be spatially manipulated to puncture the cell membrane $[31,32]$.

In the first mode of operation of the cell poration device, i.e. seeding the cell on the substrate depicted in Figure 1(a), the penetration of nanostructure is mainly driven by the properties and the types of the cell itself. Puncturing the plasma membrane of the stiffer cell requires less strain and tension compared to the softer cell. Experimental observation shows that lipid membrane could fail when the tension is 1-10 $\mathrm{mN} / \mathrm{m}$ and the rupture strain is $1-5 \%$ [33-35]. Using mechanical model, Xie and coworkers calculated critical tension of membrane failure of $5.6 \mathrm{mN} / \mathrm{m}$ and varying rupture strain: $0.7 \%$ for a stiff cell, $2 \%$ for a regular cell, and $6 \%$ for a soft cell [30]. The critical tension value does not assure membrane penetration; it only indicates a threshold value above which penetration of nanowire will start occurring. The mechanisms of how vertical nanowire breaks the cell membrane are described in two ways: impaling and adhesion. The impaling mechanism specifies that the penetration occurs when the rounded cell initially contacts the nanowire and the membrane is deformed by the gravitational force. Therefore, the cell does not well adhere to the substrate. On the other hand, the adhesion-mediated mechanism affirms that the cell membrane deformation occurs over a longer period of time compared to the impaling mechanism. The binding of the cell membrane onto the substrate induces a local force between the nanowire and the membrane. The former mechanism is suitable to explain the membrane penetration for cells that are typically grown in suspensions such as B cell and T cell of the lymphocyte family. However, the impaling mechanism also suggests that higher aspect ratio and smaller diameter nanowire is vital to break the cell membrane compared to adhesion-mediated cell membrane disruption. Shalek et al demonstrate experimentally that longer and sharper nanowire with height 2-3 um and a diameter less than $150 \mathrm{~nm}$ is required to ensure effective penetration into mouse B and T cells [36]. Unfortunately, this long and sharp nanowire will reduce the viability of adherent cells which is likely caused by nuclear penetration. From their result, obviously, the size and geometry of the nanostructure also define the poration performance of the device. Extensive study has shown that the nanoneedle with cylindrical shape and diameter of less than $400 \mathrm{~nm}$ can penetrate non-invasively into human epidermal melanocyte, HEK293 cell, and breast cancer-derived MCF-7 cell [37]. By increasing the diameter up to $800 \mathrm{~nm}$, the nanoneedle starts to compromise the viability of all the aforementioned cells.

Figure 1(b) portrays the second mode of operation which penetration is caused by controlling the nanostructure. When manipulating the nanostructure, more parameters beside the cell properties and nanostructure characteristics need to be considered. In general, the critical driving factors which determine the effectiveness of membrane poration using controllable nanostructure is how the nanostructure is being moved. The tension generated by the movement of the nanostructure on the cell membrane is determined by the force imposed to the membrane. Nanoneedle with a diameter of 200 $-300 \mathrm{~nm}$, force at around $1-2 \mathrm{nN}$ and indentation of more than $1 \mathrm{um}$ is sufficient to puncture the plasma membrane of human epidermal melanocyte $[31,38]$. Smaller diameter nanoneedle with straight side wall requires less force to penetrate the cell membrane in comparison to the larger and tapered one [38]. Combining arrays of diamond nanoneedles with diameter around $300 \mathrm{~nm}$ and centrifugation with speed $300-400 \mathrm{rpm}$, Wang et al demonstrated that the system could efficiently poke fibroblast, and even, primary neuron cells [39]. The calculated force generated by their system is approximately 2 $\mathrm{nN}$ per needle. According to Angle et al, the penetration forces required to puncture the cell membrane depends on the probe sharpness but not the properties of the cellular architecture [40]. Moreover, for low force operation, sharp nanostructure design with a tip in the size of less than $250 \mathrm{~nm}$ is suggested. A variety of single nanostructure has been conceived with multiple functionalities such as femtoliter liquid injection, molecule delivery, organelle probing, and electrical signal recording [41-44].

Using only mechanical force for cell poration is expected to not induce obnoxious cell responses due to biochemical activation which commonly occurs when using chemical agents or the viral vector $[45,46]$. Also, specific control over number and size of pores is possible. As long as the nanostructure is able to be fabricated, the desired output of how the structure breaks the cell membrane can be designed. On the other hand, the fabrication issue remains as the challenge of the widespread adoption of the mechanical nanostructure for cell membrane poration. Until now, the nanofabrication process is usually conducted in a clean room which does not come cheap. In addition to costly fabrication, the mechanical nanostructure design might need to be customized specifically for each cell type, not a kind of one- 
(a)

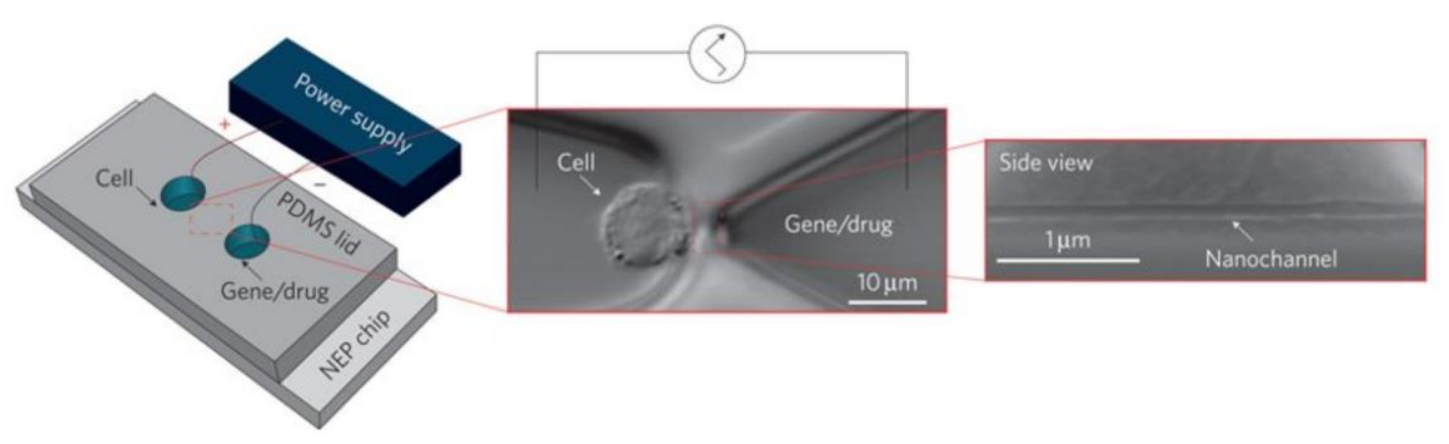

(b)
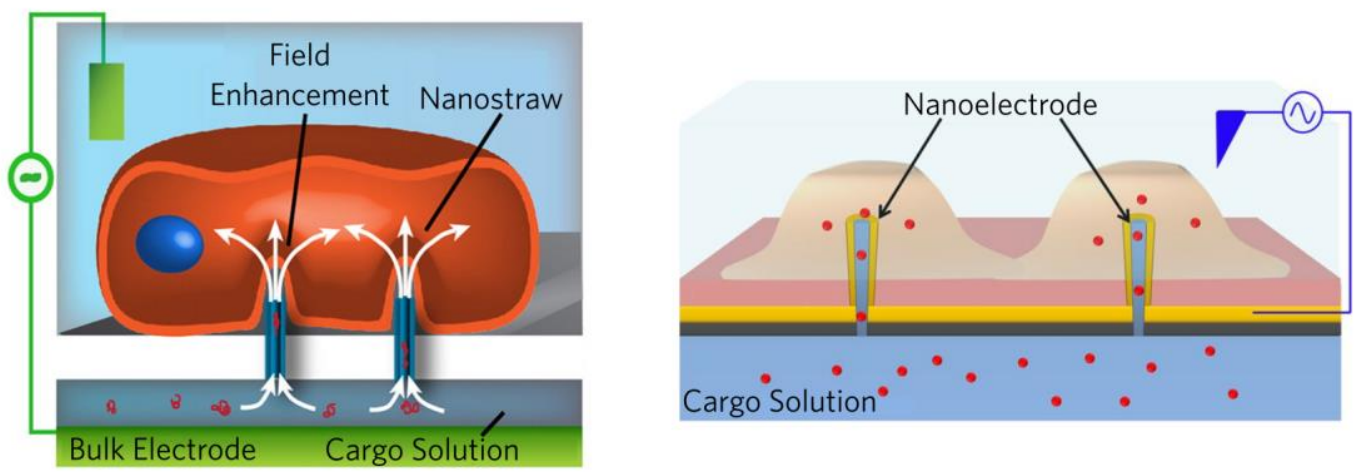

Figure 2. Design of nanoelectroporation device. (a) Single nanochannel electroporation device, adapted with permission from [52], Copyright 2011 Springer Nature. (b) Arrays of nanochannel with a bulk electrode (left) and nanochannel electrodes (right), adapted with permission from [53,54], Copyright 2013 American Chemical Society.

size-fits-all technology. The effectiveness of the nanostructure for cell poration highly depends on the suitability of the cell dimension with respect to the structure geometry. For example, too large deformation experienced by the cell can lead to harmful mechanotransduction or even DNA damage due to nuclear deformation [47-51]. Regardless of its complex design and fabrication method, the nanostructure still provides a promising future for the cell poration technology.

\section{Electroporation}

Infusing electric field via the nanostructure contributes several major advantages for cell electroporation. The commonly used bulk electroporation requires a high voltage in the order of several kilovolts and creates random pore formation on the surface of the cell membrane. The high electric field may lower the cell viability when exposing the electric field to a larger area of the cell, it may cause an ionic imbalance in the intracellular environment that could lead to cell death [55]. The $\mathrm{pH}$ around the cathode of the electroporation system is also prone to change which would be toxic to the cell [56]. In addition, some electro-sensitive particles for intracellular delivery such as quantum dots or negatively charged molecules could aggregate and dysfunction when transferred using bulk electroporation $[57,58]$. In contrast, the nanostructure mediates a localized electric field which causes gentler disruption yet effective [59]. When coupled with the nanostructure, such as carbon nanotubes or nanoelectrode gap, the required electrical input could decrease significantly due to the electrical field enhancement on the tip of the nanostructure [60-63]. The low applied voltage in the nanostructure-mediated electroporation prevents bubble formation which indicates minimal electrochemical reaction that may compromise cell viability [64]. Additionally, a high-throughput cell processing device using electroporation mechanism can be realized with low energy consumption [65].

Harnessing the nanostructure for electroporation can uncover a novel mechanism for the cell permeabilization and cargo delivery transport. The molecular transport process in bulk electroporation, which permeabilizes the cell membrane randomly on both poles facing cathode and anode, resembles the diffusion phenomenon through the long-live pores $[9,66,67]$. The diffusion process exhibits a gradual increase of the concentration of the molecule inside the cell. On the other hand, the nanochannel electroporation device as in Figure 2(a) delivers the molecule instantaneously into the cytosolic space within $30 \mathrm{~ms}$ [52]. For comparison, bulk electroporation takes $150 \mathrm{~s}$ to achieve the same delivery amount which is 3 order of magnitude slower than the nanochannel electroporation. The rapid molecule delivery is theoretically described as a result of field enhanced particle acceleration inside the channel. The nanochannel electroporation also allows precise dosage control by varying the duration of the electric pulse. The 
ability to precisely control the amount of molecule delivered into the cell is clearly unachievable using bulk electroporation.

Nanostructure arrays for electroporation can be constituted by bulk electrode or nanoelectrodes. Figure 2(b) shows these different setups. The first setup operates by exploiting the nanostructure to help enhance the electric field induced by the bulk electrode that is positioned across the nanochannel $[52,53,68]$. Clearly, the electroporation setup is similar to the bulk electroporation. Nevertheless, the presences of the nanochannel could improve the field localization when the electrical field is applied across the cell. The molecular delivery into the cell is enhanced by electrophoresis thus controlling the presence of electrical field could modulate the

(a)

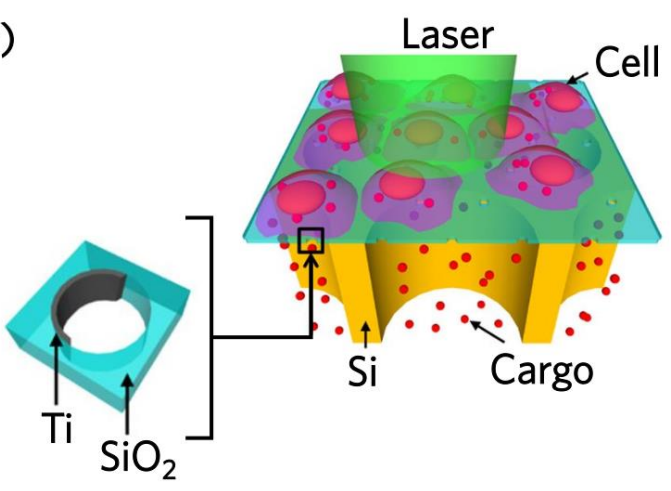

(b)

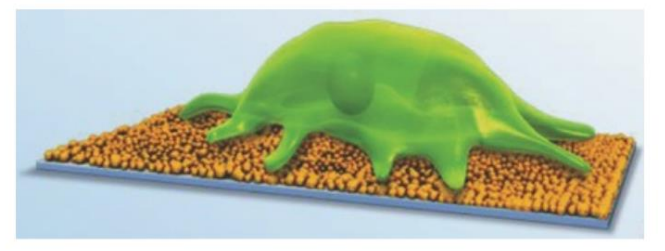

(c)

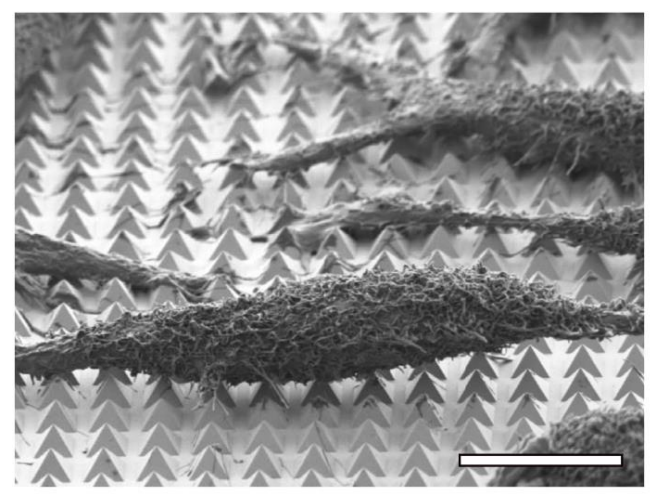

Figure 3. Plasmonic nanostructure device for membrane poration. (a) Crescent-shaped metallic nanostructure, adapted with permission from [76], Copyright 2015 Springer Nature. (b) Gold nanoparticle layer, adapted with permission from [77], Copyright 2016 John Wiley and Sons. (c) Pyramidal sharp-tip gold plasmonic substrate, adapted with permission from [78], Copyright 2017 American Chemical Society. Scale bar, $10 \mu \mathrm{m}$ amount of the delivered molecule. The second setup utilizes the nanostructure itself as the nanoelectrode $[54,69,70]$. Using the later design, selective poration of a specific cell in the same population is possible by only firing certain nanoelectrode. Beside temporal selectivity, the nanoelectrode could also act as a sensing instrument for intracellular signal recording. The nanometer-sized pores generated by the nanoelectrode increase the signal quality of the recorded cell action potential which enables real-time detection of electrical signal alteration due to drug intake [71].

The nanostructure-enabled electroporation provides localized permeabilization of the cell membrane with high intracellular delivery efficacy and minimal disruption even though the throughput is still limited. In order to ensure the localized electroporation to take effect, the cell should be in close contact and tightly sealed to the nanochannel or the nanoelectrode. Current nanostructure-mediated electroporation technology involves adhesion of the cell to the nanostructure in order to fulfill this requirement. Consequently, the system is not suitable for batch processing. For single cell application, close contact between the cell and the structure could be achieved by trapping the cell using optical or acoustic tweezer and locating the cell close to the nanostructure [72,73].

Another challenge of this technology is the complicated fabrication. The nanochannel electroporation device by Lee group exploits the DNA combing and imprinting method which is a recently developed method by their own group [74]. The nanostraw electroporation device by Melosh group combines atomic layer deposition method on membrane template followed by reactive ion etching to expose the hollow nanowire [75]. The device development requires advance knowledge in nanofabrication especially for incorporating new materials in complex geometry [70]. Until now, there are only a handful of research groups who are working on nanoelectrode device for cell study due to a limited expertise in the topic.

\section{Optical and Plasmonic Poration}

Conductive materials illuminated by electromagnetic waves that match its resonance frequency could generate a plasmonic effect which in turn produces enormous energy in the form of heat [79]. Metallic nanostructure immersed in water, for example, when irradiated with a laser, produces an explosive bubble due to superheated water [80]. The energy that either comes from the thermal heating or the bubble explosion has been used to enhance membrane permeabilization of the cell [81]. The heat generation in the plasmonic nanostructure highly depends on the shape and geometry of the nanostructure [82]. The local near-field enhancement of the plasmonic effect could be increased by tuning the morphology of the nanostructure [83]. The integration between optical laser system and metallic 
nanostructure is able to promote highly effective cell membrane poration [84].

Similar to the mechanical nanostructure, the plasmonic nanostructure that is utilized for cell membrane poration can be in a single structure as well as an arrayed fashion. Chiou group develop single nanostructure called photothermal nanoblade which can cut the cell membrane and load various cargo into a single mammalian cell, ranging from mitochondria to bacteria [85-88]. The nanostructure is fabricated by depositing a thin layer of noble metal onto the surface of the micropipette. Illuminating the metal with a continuous-wave laser would produce the vapor bubble that bolsters the breaking of the cell membrane. The process of vapor bubble generation to cell membrane disruption occurs in less than $200 \mathrm{~ns}$. This type of plasmonic nanostructure is able to create a large window in the cell membrane and at the same time maintains cell viability by conserving the cell structure and allowing rapid reseal of the cell membrane [76]. The nanostructure is intentionally fabricated in crescent shape so that it is able to slice the membrane in a "cat-door" shape [85]. This unique opening shape allows large cargo to be passed without causing too much loss of the cell membrane and cytosol content thus preserving the cell health.

Arrays of plasmonic nanostructures, moreover, could generate pore on a large amount of cell population on the substrate. Figure 3 presents various substrates that have been realized including an array of gold nanoparticles, tipless metallic nanostructures, and sharp-tip metallic nanostructures [76-78,83]. In addition, by resembling the nanochannel electroporation device, plasmonic nanotube substrate support manipulation of the type of the chemicals that need to be delivered after poration [89]. Spatial control of the poration is achievable by controlling the position of the laser beam and the amount of the laser fluence. The sharp tip plasmonic substrates by Wu et al (Figure 3(a)) and Saklayen et al (Figure $3(\mathrm{c}))$ require around $55 \mathrm{~mJ} / \mathrm{cm}^{2}$ even though the type of materials they employ is different; the former adopts thin film of titanium on silicon while the later utilizes gold pyramidal nanostructure [76,78]. On the other hand, tipless plasmonic nanostructures such as gold nanoparticle layers in Figure 3(b) require $150 \mathrm{~J} / \mathrm{cm}^{2}$ for effective cell poration which is several orders of magnitude larger than its sharp tip counterpart [77]. As a side note, high laser energy may be phototoxic and harmful for the cell viability. Nonetheless, plasmon-based cell poration device is minimally invasive to the cell considering the rapid membrane disruption involved during the poration process. In spite of that, short wavelength spectrum such as UV has been widely known as a major cause of DNA damage in the cell. Therefore, a safer device could be developed by using an infrared laser to avoid any damage to the living cell. Reducing the laser energy via short pulse laser instead of continuous illumination may inflict less cell damage even though could also compromise poration effectivity.
The utilization of laser setup might hurdle the widespread implementation of the nanoplasmonic device for cell poration. Optical setup with coherent laser source is complicated and rather unaffordable in general. The laser needs to scan the plasmonic substrate which usually occurs slowly depending on the intended laser fluence. Wu et al reported that this limit the delivery efficiency of their device [76]. The temporal delay of the plasmon activation will allow the cell to heal before the cargo can be delivered. For efficient energy transfer, the laser excitation wavelength has to be well adjusted according to the nanostructure morphology [82]. Therefore, a methodical design of the size, shape, and geometry of the nanostructure has to be done prior to fabrication because out of resonance excitation would not produce plasmon effect. Despite these challenges, the nanoplasmonic poration device can be integrated with other application such as the biosensor. Surface plasmon resonance has been intensively developed for sensing and quantization of assorted biomolecules [90]. In addition, the plasmon excitation might also be generated using electrically pumped nanolaser that can be monolithically combined with the nanostructure substrate [91-93]. These technologies will definitely improve mainstream adoption of the nanoplasmonic method for cell membrane poration in the future.

\section{Discussion}

The cell poration could provide direct access into the intracellular compartment of the cell. Naturally, cellular uptake proceeds through the endocytic pathway which is mediated by copious proteins and biomolecules [94]. The chemical substances captured with the aid of endocytosis is then consigned into the vesicle. The majority of foreign particles are perceived as a threat to the cell, therefore, the vesicle function as a trap for unwanted substances. Particles that are unable to escape will follow a degradation procedure by the lysosome. From this perspective, the ability to flee the vesicular trap is the rate-determining step for particle uptake during endocytosis. In contrast, direct cytosol access allows cargo from the extracellular environment to bypass the endosomal pathway. The creation of pore by the nanostructure could facilitate particle transport through diffusion or other physicochemical approaches which is not particularly depending on how the cell responds to the particle. Therefore, the cell poration allows delivery of cargo beyond genetic materials such as protein, artificial nanoparticles, organelles, or even bacteria. Delivering those substances into the cell may allow stem cell reprogramming, organelle labeling, measurement of the intracellular environment, and tracking the intracellular dynamics [95-98].

The delivery efficiency using the nanostructure is different for each technology based on the mode of operation, type of cell, the geometry of the structure, and the type of cargo. The majority of the single nanostructure can successfully deliver 
cargo due to precise control of the structure into the cell, or by moving the cell to the nanostructure. Earlier version of this technology employed micromanipulator to steer the nanostructure $[32,41,85,86,88,99]$. Later on, the nanostructure is often fabricated along the AFM probe, therefore, the positioning of the structure can achieve nanoscale resolution using the piezoelectric actuator $[31,37,43,59]$. For the same purpose, manipulating the cell position using optical tweezer has also been demonstrated [52]. Even though single nanostructure manipulation can deliver cargo effectively, this process limits the study into a single cell. Scaling up the cargo delivery process of the single nanostructure may be assisted by automating the nanostructure manipulation using threedimensional stage controller. The automatic stage apparatus, called CellBee, is able to handle up to 10 cells/min [100].

More favorable approach to increase the cargo delivery throughput is by applying arrays of the nanostructure and interfacing them with a population of cells. A summary of the delivery performance of nanostructure arrays is listed in Table 1. In a special case, the nanostructure arrays may perform intracellular delivery in the tissue-level domain such as plasmid DNA delivery to promote neovascularization of muscle tissue [101,102]. Various types of nanostructures have demonstrated successful cargo delivery into living cells and each of them has their own superiority over the others. Nanostructure mechanical poration requires no other supporting instrument such as the signal generator or laser setup. However, mechanical poration is usually less effective in delivering nucleic acid compared to electrical-based poration technology due to the lack of electrical driving force of the charged molecule. For electrical poration, the dosage of the delivered particle may be controlled through the amount of electric pulse. Yet, close contact of the cell and the nanostructure is required in order process to take effect. This is a huge challenge for the suspension-grown cell. Plasmonicbased nanostructure poration allows larger pore to be created without adverse effect to the cell health. But the number of the treated cell is limited to the laser scanning speed due to the typical laser beam spot only allows a small area to be exposed.

Upon cell poration by the nanostructure, treated cells can be harvested by following common cell culture procedures. Cells grown in suspension can be removed directly from the nanostructured device and restored back in the incubator for further use. Treated adherent cells are usually incubated on the device for 24 hours [103,104]. After incubation, the cells are detached by trypsin and washed. Subsequently, harvested cells can be examined by various biological assays.

In general, cell membrane poration using the nanostructures can preserve the cell viability of the cell in the range of $75 \%$ to $98 \%$. However, delivery efficiency is highly diverse (see Table 1). Small molecules, such as propidium iodide and calcein, have the highest delivery efficiency. This condition happens due to two main reasons. First, small molecules with small radius will diffuse faster due to the transport kinetics. Therefore, small molecules will accumulate quickly in the cell resulting in more delivery efficiency. Incorporating active actuator such differential pressure chamber may assist the delivery of larger molecule [76]. Although less size-dependent diffusion takes the role in the process, the delivery efficiency for large cargo is still unable to match small molecule efficiency. The second reason is the varying degree of membrane repair time depending on the wound size. Larger pore tends to be repaired faster due to $\mathrm{Ca}^{2+}$ signaling while small pore repair takes longer time thus stay stable for a longer period of time [9]. In the presence of $\mathrm{Ca}^{2+}$ ion at physiological concentration, the plasma membrane usually reseals in as few as 30 seconds [105]. Delivery of small molecules may reach up to $95 \%$ efficiency using a variety of nanostructure device. For large cargo such as bacteria, the delivery efficiency that has been achieved is $50 \%$ by plasmonic nanostructure device which offers rapid membrane poration [76]. An important thing to note is that transfection of the cell using naked DNA plasmid is less likely to succeed. Oftentimes, the nucleic acid is coupled with liposome to facilitate the transport to the nucleus [106]. Hence, cargo pre-treatment may be needed to achieve high delivery efficiency.

\section{Summary and Outlook}

In this paper, we have reviewed recent nanostructured devices for cell membrane poration. The nanostructures discussed in here utilize the physical approach to generate temporal disruption in the cell membrane. The proof-ofprinciple works described here demonstrate that nanostructure allows high delivery efficiency of various cargo into the cell without excessive reduction to cell viability. Nanostructure enables precision control over how much cargo is delivered, which cells are targeted, and when the intracellular delivery is intended, unlike bulk cell membrane poration method. The power of nanostructured device for intracellular delivery makes it possible to uncover novel biological mechanism such as the pathogen-host interaction in population-level observation instead of a single cell. Aside from cargo delivery, the nanostructured device also plays a significant role in interfacing the biosystem with engineering toolsets $[107,108]$. The tiny feature of the nanostructure is non-invasive for longterm intracellular and extracellular signal probe $[109,110]$. The details on nanostructure for cellular electrical recording have been covered elsewhere [111-115]. The nanostructure devices could also assist in developmental biology study. For example, engineering the nanostructure materials and dimension has been demonstrated to stimulate neural cultures, improve cartilage cell proliferation, and influence stem cell fate [116-120]. Nevertheless, there is still room for improvement of creative nanotechnology for cell membrane poration and cellular studies. 
It is important that future research investigate how living cell interacts with nanostructures as limited studies have been done in this area $[107,121,122]$. A serendipitous response of the cell when interacting with the structure may or may not be desired for the overall performance for cell poration. Culturing the cell in the nanostructured environment can induce various cell response such as a change in proliferation and differentiation [123,124]. Therefore, understanding cellnanostructure interfaces may provide guidance on how to optimize current technology to increase delivery efficiency without compromising cell health.

Another challenge is the limitation in nanofabrication which relying mostly on lithographic method. Until now, nanofabrication of a specific design is popularly conducted via lithography, either bottom-up or top-down approach. Even though innovative nanofabrication method has been investigated, conventional techniques such as photolithography and e-beam lithography are the ones that are widely available in academic and industrial settings [125127]. Novel research demonstrates that non-lithography techniques are able to fabricate a well-controlled nanostructure such as the vertically aligned nanowire $[128,129]$. Recently, plasmonic nanostructure for cell poration can also be fabricated using self-assembly of colloidal nanoparticle[130].

For ex vivo application like immunotherapy, a highthroughput intracellular delivery is an utmost importance. Current nanostructure device on average can achieve around $\sim 10^{5}$ cells each processing time. In the clinical trial, a processing of $10^{8}-10^{9}$ cells is required depending on the dosage [131]. To achieve this outcome, the viral vector is still a preferred choice for the adoptive immune therapy as a huge number of engineered cells can be manufactured [132]. However, engineering cells through viral vector tend to be labor intensive and handling viral agent requires some degrees of expertise. Viral vector transfection is also limited by the number and size of the gene to package [133]. Improving current nanostructured device may bridge this gap by offering high throughput cell processing. Novel nanostructure design or hybrid technology by combining multiple physical approaches may be able to unravel improved performance of the technology. The possibility offered by nanotechnology warrants more exploration for future research in cell membrane poration application.

\section{Acknowledgments}

The authors acknowledge support through the startup funds from the University of Colorado Boulder. The authors also thank the reviewers for their insightful comments.
[1] Hawiger J 1999 Current Opinion in Chemical Biology 3 89-94

[2] Rosi N L, Giljohann D A, Thaxton C S, Lytton-Jean A K R, Han M S and Mirkin C A 2006 Science 312 1027-30

[3] Maia J, Santos T, Aday S, Agasse F, Cortes L, Malva J O, Bernardino L and Ferreira L 2011 ACS Nano 5 97-106

[4] Suh J S, Lee J Y, Choi Y S, Chong P C and Park Y J 2013 Biomaterials 34 4347-59

[5] Chen A A, Derfus A M, Khetani S R and Bhatia S N 2005 Nucleic Acids Res 33 e190-e190

[6] Tan S C and Yiap B C 2009 J Biomed Biotechnol 2009

[7] Tieleman D P 2004 BMC Biochemistry 510

[8] Neumann E, Schaefer-Ridder M, Wang Y and Hofschneider P H 1982 EMBO J. 1 841-5

[9] Weaver J C and Chizmadzhev Y A 1996 Bioelectrochemistry and Bioenergetics 41 135-60

[10] Esser A T, Smith K C, Gowrishankar T R, Vasilkoski Z and Weaver J C 2010 Biophys J 98 2506-14

[11] Meacham J M, Durvasula K, Degertekin F L and Fedorov A G 2014 J Lab Autom. 19 1-18

[12] Kim H J, Greenleaf J F, Kinnick R R, Bronk J T and Bolander M E 1996 Hum. Gene Ther. 7 1339-46

[13] Bao S, Thrall B D and Miller D L 1997 Ultrasound Med Biol 23 953-9

[14] Greenleaf W J, Bolander M E, Sarkar G, Goldring M B and Greenleaf J F 1998 Ultrasound in Medicine \& Biology 24 587-95

[15] Furth P A, Shamay A, Wall R J and Hennighausen L 1992 Analytical Biochemistry 205 365-8

[16] Sharei A, Zoldan J, Adamo A, Sim W Y, Cho N, Jackson E, Mao S, Schneider S, Han M-J, Lytton-Jean A, Basto P A, Jhunjhunwala S, Lee J, Heller D A, Kang J W, Hartoularos G C, Kim K-S, Anderson D G, Langer R and Jensen K F 2013 PNAS 110 2082-7

[17] Palumbo G, Caruso M, Crescenzi E, Tecce M F, Roberti G and Colasanti A 1996 Journal of Photochemistry and Photobiology B: Biology 36 41-6

[18] Schneckenburger H, Hendinger A, Sailer R, Strauss W S L, Lyttek M and Schmitt M 2002 JBO, JBOPFO 7 410-7

[19] Uchugonova A, König K, Bueckle R, Isemann A and Tempea G 2008 Opt. Express, OE 16 9357-64

[20] Baumgart J, Humbert L, Boulais É, Lachaine R, Lebrun J$\mathrm{J}$ and Meunier M 2012 Biomaterials 33 2345-50

[21] Farokhzad O C and Langer R 2009 ACS Nano 3 16-20

[22] Xu A M, Aalipour A, Leal-Ortiz S, Mekhdjian A H, Xie X, Dunn A R, Garner C C and Melosh N A 2014 Nature Communications 53613

[23] Matsumoto D, Sathuluri R R, Kato Y, Silberberg Y R, Kawamura R, Iwata F, Kobayashi T and Nakamura C 2015 Scientific Reports 515325

[24] Lewis B A and Engelman D M 1983 Journal of Molecular Biology 166 211-7

[25] Carlo D D, Jeong K-H and Lee L P 2003 Lab Chip $3287-$ 91

[26] Yun S-S, Yoon S Y, Song M-K, Im S-H, Kim S, Lee J-H and Yang S 2010 Lab Chip 10 1442-6

[27] Kim J, Hong J W, Kim D P, Shin J H and Park I 2012 Lab Chip 12 2914-21

\section{References}


[28] So H, Lee K, Seo Y H, Murthy N and Pisano A P 2014 ACS Appl. Mater. Interfaces 6 6993-7

[29] So H, Lee K, Murthy N and Pisano A P 2014 ACS Appl. Mater. Interfaces 6 20693-9

[30] Xie X, Xu A M, Angle M R, Tayebi N, Verma P and Melosh N A 2013 Nano Lett. 13 6002-8

[31] Obataya I, Nakamura C, Han, Nakamura N and Miyake J 2005 Nano Lett. 5 27-30

[32] Schrlau M G, Falls E M, Ziober B L and Bau H H 2008 Nanotechnology 19015101

[33] Evans E, Heinrich V, Ludwig F and Rawicz W 2003 Biophysical Journal 85 2342-50

[34] Sen S, Subramanian S and Discher D E 2005 Biophysical Journal 89 3203-13

[35] Verma P, Wong I Y and Melosh N A 2010 Biointerphases $537-44$

[36] Shalek A K, Gaublomme J T, Wang L, Yosef N, Chevrier N, Andersen M S, Robinson J T, Pochet N, Neuberg D, Gertner R S, Amit I, Brown J R, Hacohen N, Regev A, Wu C J and Park H 2012 Nano Lett. 12 6498-504

[37] Han S, Nakamura C, Obataya I, Nakamura N and Miyake J 2005 Biochemical and Biophysical Research Communications 332 633-9

[38] Obataya I, Nakamura C, Han S, Nakamura N and Miyake J 2005 Biosensors and Bioelectronics 20 1652-5

[39] Wang Y, Yang Y, Yan L, Kwok S Y, Li W, Wang Z, Zhu X, Zhu G, Zhang W, Chen X and Shi P 2014 Nature Communications 54466

[40] Angle M R, Wang A, Thomas A, Schaefer A T and Melosh N A 2014 Biophysical Journal 107 2091-100

[41] Knoblauch M, Hibberd J M, Gray J C and Bel A J E van 1999 Nature Biotechnology 17 906-9

[42] Kouklin N A, Kim W E, Lazareck A D and Xu J M 2005 Appl. Phys. Lett. 87173901

[43] Chen X, Kis A, Zettl A and Bertozzi C R 2007 PNAS 104 8218-22

[44] Singhal R, Orynbayeva Z, Sundaram R V K, Niu J J, Bhattacharyya S, Vitol E A, Schrlau M G, Papazoglou E S, Friedman G and Gogotsi Y 2011 Nature Nanotechnology 6 57-64

[45] Thomas C E, Ehrhardt A and Kay M A 2003 Nature Reviews Genetics 4 346-58

[46] Jin L, Zeng X, Liu M, Deng Y and He N 2014 Theranostics 4 240-55

[47] Charras G T and Horton M A 2002 Biophysical Journal 82 2970-81

[48] Denais C M, Gilbert R M, Isermann P, McGregor A L, Lindert M te, Weigelin B, Davidson P M, Friedl P, Wolf K and Lammerding J 2016 Science 352 353-8

[49] Irianto J, Xia Y, Pfeifer C R, Athirasala A, Ji J, Alvey C, Tewari M, Bennett R R, Harding S M, Liu A J, Greenberg R A and Discher D E 2017 Current Biology 27 210-23

[50] Anon 2017 Biophysical Journal 112 446-9

[51] Anon 2017 Biophysical Journal 112 2271-9

[52] Boukany P E, Morss A, Liao W, Henslee B, Jung H, Zhang X, Yu B, Wang X, Wu Y, Li L, Gao K, Hu X, Zhao X, Hemminger O, Lu W, Lafyatis G P and Lee L J 2011 Nature Nanotechnology 6 747-54
[53] Xie X, Xu A M, Leal-Ortiz S, Cao Y, Garner C C and Melosh N A 2013 ACS Nano 7 4351-8

[54] Caprettini V, Cerea A, Melle G, Lovato L, Capozza R, Huang J-A, Tantussi F, Dipalo M and Angelis F D 2017 Scientific Reports 78524

[55] Gehl J Acta Physiologica Scandinavica 177 437-47

[56] Li Y, Wu M, Zhao D, Wei Z, Zhong W, Wang X, Liang Z and Li Z 2015 Scientific Reports 517817

[57] Golzio M, Teissié J and Rols M-P 2002 PNAS 99 1292-7

[58] Derfus A M, Chan W C W and Bhatia S N Advanced Materials 16 961-6

[59] Kang W, Yavari F, Minary-Jolandan M, Giraldo-Vela J P, Safi A, McNaughton R L, Parpoil V and Espinosa H D 2013 Nano Lett. 13 2448-57

[60] Shahini M and Yeow J T W 2011 Nanotechnology 22 325705

[61] Shahini M and W. Yeow J T 2013 Lab on a Chip 13 258590

[62] Santra T S, Wang P-C, Chang H-Y and Tseng F-G 2013 Appl. Phys. Lett. 103233701

[63] Jokilaakso N, Salm E, Chen A, Millet L, Duarte Guevara C, Dorvel B, Reddy B, Eriksson Karlstrom A, Chen Y, Ji H, Chen Y, Sooryakumar R and Bashir R 2013 Lab on a Chip 13 336-9

[64] Riaz K, Leung S-F, Fan Z and Lee Y-K 2017 Sensors and Actuators A: Physical 255 10-20

[65] Liu C, Xie X, Zhao W, Liu N, Maraccini P A, Sassoubre L M, Boehm A B and Cui Y 2013 Nano Lett. 13 4288-93

[66] Pavlin M, Leben V and Miklavčič D 2007 Biochimica et Biophysica Acta (BBA) - General Subjects 1770 12-23

[67] Pavlin M and Miklavčič D 2008 Bioelectrochemistry 74 38-46

[68] Chang L, Bertani P, Gallego-Perez D, Yang Z, Chen F, Chiang C, Malkoc V, Kuang T, Gao K, James Lee L and Lu W 2016 Nanoscale 8 243-52

[69] Xie C, Lin Z, Hanson L, Cui Y and Cui B 2012 Nature Nanotechnology 7 185-90

[70] Lin Z C, Xie C, Osakada Y, Cui Y and Cui B 2014 Nature Communications 53206

[71] Duan X, Gao R, Xie P, Cohen-Karni T, Qing Q, Choe H S, Tian B, Jiang X and Lieber C M 2012 Nature Nanotechnology 7 174-9

[72] Ashkin A, Dziedzic J M, Bjorkholm J E and Chu S 1986 Opt. Lett., OL 11 288-90

[73] Ding X, Lin S-C S, Kiraly B, Yue H, Li S, Chiang I-K, Shi J, Benkovic S J and Huang T J 2012 PNAS 109 11105-9

[74] Guan J, Boukany P E, Hemminger O, Chiou N-R, Zha W, Cavanaugh M and Lee L J Advanced Materials 22 39974001

[75] VanDersarl J J, Xu A M and Melosh N A 2012 Nano Lett. 12 3881-6

[76] Wu Y-C, Wu T-H, Clemens D L, Lee B-Y, Wen X, Horwitz M A, Teitell M A and Chiou P-Y 2015 Nature Methods 12 439-44

[77] Lyu Z, Zhou F, Liu Q, Xue H, Yu Q and Chen H Advanced Functional Materials 26 5787-95

[78] Saklayen N, Huber M, Madrid M, Nuzzo V, Vulis D I, Shen W, Nelson J, McClelland A A, Heisterkamp A and Mazur E 2017 ACS Nano 11 3671-80 
[79] Govorov A O, Zhang W, Skeini T, Richardson H, Lee J and Kotov N A 2006 Nanoscale Res Lett 184

[80] Wang Y, Zaytsev M E, Lajoinie G, The H L, Eijkel J C T, Berg A van den, Versluis M, Weckhuysen B M, Zhang X, Zandvliet H J W and Lohse D 2018 PNAS 201805912

[81] Xiong R, Raemdonck K, Peynshaert K, Lentacker I, De Cock I, Demeester J, De Smedt S C, Skirtach A G and Braeckmans K 2014 ACS Nano 8 6288-96

[82] Baffou G, Quidant R and Girard C 2009 Appl. Phys. Lett. 94153109

[83] Courvoisier S, Saklayen N, Huber M, Chen J, Diebold E D, Bonacina L, Wolf J-P and Mazur E 2015 Nano Lett. 15 4461-6

[84] Saklayen N, Kalies S, Madrid M, Nuzzo V, Huber M, Shen W, Sinanan-Singh J, Heinemann D, Heisterkamp A and Mazur E 2017 Biomed. Opt. Express, BOE 8 4756-71

[85] Wu T-H, Teslaa T, Teitell M A and Chiou P-Y 2010 Opt. Express, OE 18 23153-60

[86] Wu T-H, Teslaa T, Kalim S, French C T, Moghadam S, Wall R, Miller J F, Witte O N, Teitell M A and Chiou P-Y 2011 Anal. Chem. 83 1321-7

[87] Xu J, Teslaa T, Wu T-H, Chiou P-Y, Teitell M A and Weiss S 2012 Nano Lett. 12 5669-72

[88] Wu T-H, Sagullo E, Case D, Zheng X, Li Y, Hong J S, TeSlaa T, Patananan A N, McCaffery J M, Niazi K, Braas D, Koehler C M, Graeber T G, Chiou P-Y and Teitell M A 2016 Cell Metabolism 23 921-9

[89] Messina G C, Dipalo M, Rocca R L, Zilio P, Caprettini V, Zaccaria R P, Toma A, Tantussi F, Berdondini L and Angelis F D Advanced Materials 27 7145-9

[90] Mullett W M, Lai E P C and Yeung J M 2000 Methods 22 77-91

[91] Duan X, Huang Y, Agarwal R and Lieber C M 2003 Nature 421 241-5

[92] Ellis B, Mayer M A, Shambat G, Sarmiento T, Harris J, Haller E E and Vučković J 2011 Nature Photonics 5 297300

[93] Chen R, Tran T-T D, Ng K W, Ko W S, Chuang L C, Sedgwick F G and Chang-Hasnain C 2011 Nature Photonics 5 170-5

[94] Doherty G J and McMahon H T 2009 Annual Review of Biochemistry 78 857-902

[95] Shah D A, Kwon S-J, Bale S S, Banerjee A, Dordick J S and Kane R S 2011 Biomaterials 32 3210-9

[96] Kucsko G, Maurer P C, Yao N Y, Kubo M, Noh H J, Lo P K, Park H and Lukin M D 2013 Nature 500 54-8

[97] Heller D A, Baik S, Eurell T E and Strano M S 2005 Advanced Materials 17 2793-9

[98] Fakhri N, Wessel A D, Willms C, Pasquali M, Klopfenstein D R, MacKintosh F C and Schmidt C F 2014 Science 344 1031-5

[99] Yum K, Na S, Xiang Y, Wang N and Yu M-F 2009 Nano Lett. $92193-8$

[100] Hara C, Tateyama K, Akamatsu N, Imabayashi H, Karaki K, Nomura N, Okano H and Miyawaki A 2006 Brain Cell Bio 35 229-37

[101] Chiappini C, Rosa E D, Martinez J O, Liu X, Steele J, Stevens M M and Tasciotti E 2015 Nature Materials 14 532-9
[102] Chiappini C, Martinez J O, De Rosa E, Almeida C S, Tasciotti E and Stevens M M 2015 ACS Nano 9 5500-9

[103] Shalek A K, Robinson J T, Karp E S, Lee J S, Ahn D-R, Yoon M-H, Sutton A, Jorgolli M, Gertner R S, Gujral T S, MacBeath G, Yang E G and Park H 2010 PNAS 107 18705

[104] Cao Y, Chen H, Qiu R, Hanna M, Ma E, Hjort M, Zhang A, Lewis R S, Wu J C and Melosh N A 2018 Science Advances 4 eaat8131

[105] Sharei A, Poceviciute R, L. Jackson E, Cho N, Mao S, C. Hartoularos G, Y. Jang D, Jhunjhunwala S, Eyerman A, Schoettle T, Langer R and F. Jensen K 2014 Integrative Biology 6 470-5

[106] Felgner P L, Gadek T R, Holm M, Roman R, Chan H W, Wenz M, Northrop J P, Ringold G M and Danielsen M 1987 PNAS 84 7413-7

[107] Tian B, Xu S, Rogers J A, Cestellos-Blanco S, Yang P, Carvalho-de-Souza J L, Bezanilla F, Liu J, Bao Z, Hjort M, Cao Y, Nicholas Melosh, Lanzani G, Benfenati F, Galli G, Gygi F, Kautz R, Gorodetsky A A, Kim S S, Lu T K, Anikeeva P, Cifra M, Krivosudský O, Daniel Havelka and Jiang Y 2018 Phys. Biol. 15031002

[108] Jiang Y, Li X, Liu B, Yi J, Fang Y, Shi F, Gao X, Sudzilovsky E, Parameswaran R, Koehler K, Nair V, Yue J, Guo K, Fang Y, Tsai H-M, Freyermuth G, Wong R C S, Kao C-M, Chen C-T, Nicholls A W, Wu X, Shepherd G M G and Tian B 2018 Nature Biomedical Engineering 2508

[109] Robinson J T, Jorgolli M, Shalek A K, Yoon M-H, Gertner R S and Park H 2012 Nature Nanotechnology 7 $180-4$

[110] Abbott J, Ye T, Qin L, Jorgolli M, Gertner R S, Ham D and Park H 2017 Nature Nanotechnology 12 460-6

[111] Alivisatos A P, Andrews A M, Boyden E S, Chun M, Church G M, Deisseroth K, Donoghue J P, Fraser S E, Lippincott-Schwartz J, Looger L L, Masmanidis S, McEuen P L, Nurmikko A V, Park H, Peterka D S, Reid C, Roukes M L, Scherer A, Schnitzer M, Sejnowski T J, Shepard K L, Tsao D, Turrigiano G, Weiss P S, Xu C, Yuste R and Zhuang X 2013 ACS Nano 7 1850-66

[112] Tian B and Lieber C M 2013 Annual Review of Analytical Chemistry 6 31-51

[113] Zhang A and Lieber C M 2016 Chem. Rev. 116 215-57

[114] Parameswaran R and Tian B 2018 Acc. Chem. Res. 51 1014-22

[115] Abbott J, Ye T, Ham D and Park H 2018 Acc. Chem. Res. 51 600-8

[116] Hällström W, Mårtensson T, Prinz C, Gustavsson P, Montelius L, Samuelson L and Kanje M 2007 Nano Lett. 7 2960-5

[117] Piret G, Perez M-T and Prinz C N 2015 ACS Appl. Mater. Interfaces 7 18944-8

[118] Oh S, Daraio C, Chen L-H, Pisanic T R, Fiñones R R and Jin S 2006 Journal of Biomedical Materials Research Part A 78A 97-103

[119] Oh S, Brammer K S, Li Y S J, Teng D, Engler A J, Chien S and Jin S 2009 PNAS 106 2130-5

[120] Dalby M J, Gadegaard N and Oreffo R O C 2014 Nature Materials 13 558-69 
[121] Capozza R, Caprettini V, Gonano C A, Bosca A, Moia F, Santoro F and De Angelis F 2018 ACS Appl. Mater. Interfaces 10 29107-14

[122] Dipalo M, McGuire A F, Lou H-Y, Caprettini V, Melle G, Bruno G, Lubrano C, Matino L, Li X, De Angelis F, Cui B and Santoro F 2018 Nano Lett. 18 6100-5

[123] Ding Y, Yang Z, Bi C W C, Yang M, Xu S L, Lu X, Huang N, Huang P and Leng Y 2014 ACS Appl. Mater. Interfaces 6 12062-70

[124] Persson H, Li Z, Tegenfeldt J O, Oredsson S and Prinz C N 2015 Scientific Reports 518535

[125] Gates B D, Xu Q, Love J C, Wolfe D B and Whitesides G M 2004 Annual Review of Materials Research 34 33972

[126] Gates B D, Xu Q, Stewart M, Ryan D, Willson C G and Whitesides G M 2005 Chem. Rev. 105 1171-96

[127] Vazquez-Mena O, Gross L, Xie S, Villanueva L G and Brugger J 2015 Microelectronic Engineering 132 236-54

[128] Chern W, Hsu K, Chun I S, Azeredo B P de, Ahmed N, Kim K-H, Zuo J, Fang N, Ferreira P and Li X 2010 Nano Lett. 10 1582-8

[129] Azeredo B P, Sadhu J, Ma J, Jacobs K, Kim J, Lee K, Eraker J H, Li X, Sinha S, Fang N, Ferreira P and Hsu K 2013 Nanotechnology 24225305

[130] Madrid M, Saklayen N, Shen W, Huber M, Vogel N and Mazur E 2018 ACS Appl. Bio Mater.

[131] Lee D W, Kochenderfer J N, Stetler-Stevenson M, Cui Y K, Delbrook C, Feldman S A, Fry T J, Orentas R, Sabatino M, Shah N N, Steinberg S M, Stroncek D, Tschernia N, Yuan C, Zhang H, Zhang L, Rosenberg S A, Wayne A S and Mackall C L 2015 The Lancet 385 517-28
[132] Tumaini B, Lee D W, Lin T, Castiello L, Stroncek D F, Mackall C, Wayne A and Sabatino M 2013 Cytotherapy 15 1406-15

[133] Kay M A 2011 Nature Reviews Genetics 12 316-28

[134] Chen X, Zhu G, Yang Y, Wang B, Yan L, Zhang K Y, Lo K K-W and Zhang W Advanced Healthcare Materials 2 $1103-7$

[135] Park S, Choi S-O, Paik S, Choi S, Allen M and Prausnitz M 2016 Biomed Microdevices 1810

[136] Matsumoto D, Yamagishi A, Saito M, Sathuluri R R, Silberberg Y R, Iwata F, Kobayashi T and Nakamura C 2016 Journal of Bioscience and Bioengineering 122 74852

[137] Mann D G J, McKnight T E, McPherson J T, Hoyt P R, Melechko A V, Simpson M L and Sayler G S 2008 ACS Nano 2 69-76

[138] McKnight T E, Melechko A V, Griffin G D, Guillorn M A, Merkulov V I, Serna F, Hensley D K, Doktycz M J, Lowndes D H and Simpson M L 2003 Nanotechnology 14 551

[139] Park S, Kim Y-S, Kim W B and Jon S 2009 Nano Lett. 9 1325-9

[140] Peer E, Artzy-Schnirman A, Gepstein L and Sivan U 2012 ACS Nano 6 4940-6

[141] Kim K H, Kim J, Choi J S, Bae S, Kwon D, Park I, Kim D H and Seo T S Small 11 6215-24

[142] Chang L, Gallego-Perez D, Zhao X, Bertani P, Yang Z, Chiang C-L, Malkoc V, Shi J, K. Sen C, Odonnell L, Yu J, Lu W and James Lee L 2015 Lab on a Chip 15 3147-53 
Table 1. Nanostructure Arrays for Intracellular Delivery

\begin{tabular}{|c|c|c|c|c|c|c|}
\hline No. & $\begin{array}{c}\text { Type of Nanostructure } \\
\text { Arrays }\end{array}$ & $\begin{array}{l}\text { Transduction } \\
\text { Principle }\end{array}$ & Type of Cell & $\begin{array}{l}\text { Type of } \\
\text { Cargo }\end{array}$ & $\begin{array}{c}\text { Delivery Performance: } \\
\text { Delivery Efficiency (\%D) } \\
\text { Cell Viability }(\% \mathrm{~V})\end{array}$ & Remarks \\
\hline 1. & $\begin{array}{c}\text { Vertically aligned silicon } \\
\text { nanowire }[36,103] \\
\text { Diameter }<150 \mathrm{~nm} \\
\text { Height }=1-3 \mu \mathrm{m}\end{array}$ & Mechanical & $\begin{array}{c}\text { Dendritic cells } \\
\text { B cells } \\
\text { T cells } \\
\text { Macrophages } \\
\text { NK Cells } \\
\text { NIH3T3 } \\
\text { Hippocampal neuron }\end{array}$ & $\begin{array}{l}\text { DNA } \\
\text { RNA } \\
\text { Protein }\end{array}$ & $\begin{array}{l}\% \mathrm{D}<95 \% \\
\% \mathrm{~V}<95 \%\end{array}$ & $\begin{array}{l}\text { Effective for various } \\
\text { immune cells }\end{array}$ \\
\hline 2. & $\begin{array}{c}\text { Diamond nanoneedle array } \\
\qquad[39,134] \\
\text { Diameter }=300-500 \mathrm{~nm} \\
\text { Height }=4.5-7.5 \mu \mathrm{m}\end{array}$ & Mechanical & $\begin{array}{c}\text { NIH3T3 } \\
\text { A549 } \\
\text { Hippocampal neuron }\end{array}$ & $\begin{array}{l}\text { EthD-1 } \\
\text { Dextran } \\
\text { QD } \\
\text { Antibody } \\
\text { DNA }\end{array}$ & $\begin{array}{c}\% \text { D: EthD- } 1<80 \% \\
\% \text { D: } 3 \mathrm{k} \text { Dextran }<60 \% \\
\% \text { D: } 20 \mathrm{~nm} \text { QD }<60 \% \\
\% \mathrm{D}: \text { Antibody }<35.5 \% \\
\% \mathrm{D}: \text { DNA }<45 \% \\
\% \mathrm{~V}<92 \%\end{array}$ & $\begin{array}{c}\text { Implemented using } \\
\text { common centrifugation } \\
\text { system }\end{array}$ \\
\hline 3. & $\begin{array}{l}\text { Microfabricated silicon } \\
\text { nanoneedle arrays with } \\
\text { tapered wall [135] or } \\
\text { straight wall }[23,136] \\
\text { Diameter }=23-200 \mathrm{~nm} \\
\text { Height }=12-25 \mu \mathrm{m}\end{array}$ & Mechanical & $\begin{array}{c}\text { HeLa } \\
\text { NIH3T3 } \\
\text { DU145 }\end{array}$ & $\begin{array}{l}\text { Dextran } \\
\text { Protein } \\
\text { DNA }\end{array}$ & $\begin{array}{c}\% \text { D: } 70 \mathrm{k} \text { Dextran }<40 \% \\
\% \text { D: Cre enzyme }<40 \% \\
\% \text { D: DNA }<34 \% \\
\% \mathrm{~V}<90 \%\end{array}$ & $\begin{array}{l}\text { Higher delivery } \\
\text { performance by } \\
\text { oscillating the } \\
\text { nanostructure }\end{array}$ \\
\hline 4. & $\begin{array}{c}\text { Vertically aligned carbon } \\
\text { nanofiber arrays for RNAi } \\
\qquad 137,138] \\
\text { Diameter }=100 \mathrm{~nm} \\
\text { Height }=10-17 \mu \mathrm{m}\end{array}$ & Mechanical & CHO-K1 & $\begin{array}{l}\text { shRNA } \\
\text { DNA }\end{array}$ & $\begin{array}{c}\% \text { D: } \text { shRNA }<89 \% \\
\% \text { D: } 2 \text { DNAs }<76.7 \%\end{array}$ & $\begin{array}{l}\text { Co-delivery of multiple } \\
\text { genes }\end{array}$ \\
\hline 5. & $\begin{array}{c}\text { Carbon nano-syringe array } \\
{[139]} \\
\text { Diameter }=50 \mathrm{~nm} \\
\text { Height }=40-160 \mathrm{~nm}\end{array}$ & Mechanical & NIH3T3 & DNA & $\begin{array}{l}\% \mathrm{D}<34 \% \\
\% \mathrm{~V}<85 \%\end{array}$ & $\begin{array}{l}\text { Hollow tubes of the } \\
\text { nanosyringe allows } \\
\text { cargo loading prior to } \\
\text { cell poration }\end{array}$ \\
\hline 6. & $\begin{array}{c}\text { Silicon hollow nanoneedle } \\
\text { array }[140] \\
\text { Diameter }=250-500 \mathrm{~nm} \\
\text { Height }=5 \mu \mathrm{m}\end{array}$ & Mechanical & $\begin{array}{l}\text { NIH3T3 } \\
\text { HEK293 }\end{array}$ & $\begin{array}{l}\text { Dextran } \\
\text { DNA }\end{array}$ & $\% \mathrm{D}<70 \%$ & $\begin{array}{c}\text { Requiring saponin for } \\
\text { delivery }\end{array}$ \\
\hline 7. & $\begin{array}{c}\text { Nanostraw [75] } \\
\text { Diameter }=100 \mathrm{~nm} \\
\text { Height }=1 \mu \mathrm{m}\end{array}$ & Mechanical & $\begin{array}{l}\mathrm{CHO} \\
\mathrm{HeLa}\end{array}$ & $\begin{array}{l}\text { Ion } \\
\text { Dye } \\
\text { DNA }\end{array}$ & $\begin{array}{c}\% \mathrm{D}: \mathrm{Co}^{2+}<70 \% \\
\% \text { D: Alexa Fluor }<40 \% \\
\% \text { D: DNA }<10 \%\end{array}$ & $\begin{array}{l}\text { Highly dense structures } \\
\text { at around } 10^{7} \text { straws } / \mathrm{cm}^{2}\end{array}$ \\
\hline 8. & $\begin{array}{c}\text { ZnO Nanowire in } \\
\text { microchannel } \\
\quad[141] \\
\text { Diameter }=37 \mathrm{~nm} \\
\text { Height }=530 \mathrm{~nm}\end{array}$ & Mechanical & MCF-7 & $\begin{array}{l}\text { Molecular } \\
\text { beacon }\end{array}$ & $\begin{array}{l}\% \mathrm{D}<59 \% \\
\% \mathrm{~V}<83 \%\end{array}$ & $\begin{array}{l}\text { Pressure-driven } \\
\text { microchannel utilizing } \\
\text { PDMS membrane to } \\
\text { move cell to the } \\
\text { nanowire }\end{array}$ \\
\hline 9. & $\begin{array}{c}\text { Silicon nanochannel } \\
\text { electroporation }[68,142] \\
\text { Pore size }=650 \mathrm{~nm}\end{array}$ & Electrical & $\begin{array}{c}\mathrm{H} 9 \mathrm{C} 2 \\
\mathrm{NK}-92 \\
\text { Mouse embryonic } \\
\text { fibroblast }\end{array}$ & $\begin{array}{l}\text { Nucleotide } \\
\text { DNA }\end{array}$ & $\begin{array}{c}\% \mathrm{D}: \text { ODN }<73 \% \\
\% \mathrm{D}: \mathrm{DNA}<74 \% \\
\% \mathrm{D}: \text { OSKM }<10 \% \\
\% \mathrm{~V}<90 \%\end{array}$ & $\begin{array}{c}\text { Precise control over } \\
\text { delivered cargo at single } \\
\text { cell level }\end{array}$ \\
\hline 10. & $\begin{array}{l}\text { Aluminum nanospike } \\
\text { electroporation [64] }\end{array}$ & Electrical & $\mathrm{HeLa}$ & $\begin{array}{l}\text { Propidium } \\
\text { iodide }(\mathrm{PI})\end{array}$ & $\begin{array}{l}\% \mathrm{D}<93 \% \\
\% \mathrm{~V}<93 \%\end{array}$ & $\begin{array}{c}\text { Low voltage operation } \\
\text { without any bubble } \\
\text { generation }\end{array}$ \\
\hline
\end{tabular}




\begin{tabular}{|c|c|c|c|c|c|c|}
\hline 11. & $\begin{array}{c}\text { Nanostraw electroporation } \\
{[53]} \\
\text { Diameter }=250 \mathrm{~nm} \\
\text { Height }=1.5 \mu \mathrm{m}\end{array}$ & Electrical & $\begin{array}{c}\text { CHO } \\
\text { HEK293 }\end{array}$ & $\begin{array}{c}\text { PI } \\
\text { DNA }\end{array}$ & $\begin{array}{c}\% \mathrm{D}: \text { PI }<95 \% \\
\% \text { D: DNA }<81 \% \\
\% \text { D: } 2 \text { DNAs }<74 \% \\
\% \mathrm{~V}<95 \%\end{array}$ & $\begin{array}{c}\text { Dosage control and co- } \\
\text { delivery of multiple } \\
\text { genes }\end{array}$ \\
\hline 12. & $\begin{array}{l}\text { Hollow nanoelectrodes [54] } \\
\text { Diameter }=400 \mathrm{~nm} \text { (outer), } \\
250 \mathrm{~nm} \text { (inner) } \\
\text { Height }=1.8 \mu \mathrm{m}\end{array}$ & Electrical & NIH3T3 & PI & $\begin{array}{l}\% \mathrm{D}<80 \% \\
\% \mathrm{~V}<98 \%\end{array}$ & $\begin{array}{l}\text { Low voltage with spatial } \\
\text { control }\end{array}$ \\
\hline 13. & $\begin{array}{l}\text { Gold nanoparticle layers } \\
\text { [77] } \\
\text { Roughness }=500 \mathrm{~nm}\end{array}$ & Plasmonic & $\begin{array}{c}\text { HeLa } \\
\text { HUVEC } \\
\text { Mouse embryonic } \\
\text { fibroblast }\end{array}$ & $\begin{array}{l}\text { Dextran } \\
\text { DNA }\end{array}$ & $\begin{array}{c}\% \text { D: } 4.4 \mathrm{k} \text { Dextran }<54 \% \\
\% \mathrm{D}: \text { DNA }<53 \% \\
\% \mathrm{~V}<95 \%\end{array}$ & $\begin{array}{l}\text { 4-fold transfection } \\
\text { efficiency compared to } \\
\text { lipofection }\end{array}$ \\
\hline 14. & $\begin{array}{c}\text { Plasmonic pyramid array } \\
\text { substrate }[78,84] \\
\text { Base length }=2.4 \mu \mathrm{m} \\
\text { Height }=1.4 \mu \mathrm{m}\end{array}$ & Plasmonic & $\mathrm{HeLa}$ & $\begin{array}{l}\text { Calcein } \\
\text { Dextran }\end{array}$ & $\begin{array}{c}\text { \% : Calcein }<95 \% \\
\% \mathrm{D}: 10 \mathrm{k} \text { Dextran }<79 \% \\
\% \mathrm{D}: \text { 70k Dextran }<70 \% \\
\% \mathrm{D}: 150 \mathrm{k} \text { Dextran }<68 \% \\
\% \mathrm{D}: 500 \mathrm{k} \text { Dextran }<24 \% \\
\% \mathrm{D}: 2 \mathrm{~m} \text { Dextran }<16 \% \\
\% \mathrm{~V}<98 \%\end{array}$ & $\begin{array}{l}\text { Handle up to } 50,000 \\
\text { cells } / \mathrm{min}\end{array}$ \\
\hline 15. & $\begin{array}{l}\text { Biopohotonic laser-assisted } \\
\text { surgery tool [76] } \\
3 \mu \mathrm{m} \text { diameter of hole } \\
\text { arrays with crescent-shaped } \\
\text { Ti nanostructure }\end{array}$ & Plasmonic & $\begin{array}{c}\text { HeLa } \\
\text { NHDF } \\
\text { PB-MDM } \\
\text { RPTEC }\end{array}$ & $\begin{array}{c}\text { Calcein } \\
\text { Dextran } \\
\text { Protein } \\
\text { Polystyrene } \\
\text { beads } \\
\text { Bacteria }\end{array}$ & $\begin{array}{c}\% \mathrm{D}: 20 \mathrm{~nm} \text { beads }<93 \% \\
\% \mathrm{D}: 200 \mathrm{~nm} \text { beads }<87 \% \\
\% \mathrm{D}: 500 \mathrm{~nm} \text { beads }<79 \% \\
\% \mathrm{D}: 1 \mu \mathrm{m} \text { beads }<75 \% \\
\% \mathrm{D}: 2 \mu \mathrm{m} \text { beads }<62 \% \\
\% \mathrm{D}: \text { Bacteria }<57.9 \% \\
\% \mathrm{~V}<90 \%\end{array}$ & $\begin{array}{l}\text { Pressure driven cargo } \\
\text { delivery system }\end{array}$ \\
\hline 16. & $\begin{array}{l}\text { Hollow plasmonic gold } \\
\text { nanotube [89] } \\
\text { Diameter = } 180 \mathrm{~nm} \text { (outer), } \\
90 \mathrm{~nm} \text { (inner) }\end{array}$ & Plasmonic & NIH3T3 & PI & - & $\begin{array}{c}\text { Spatial and temporal } \\
\text { control over porated } \\
\text { cells }\end{array}$ \\
\hline
\end{tabular}

